Stratton, professor of astrophysics and director of the Observatories, University of Cambridge ; Council, Dr. R. d'E. Atkinson, chief assistant, Royal Observatory, Greenwich ; B. C. Browne, lecturer in geodesy, University of Cambridge; Dr. H. A. Brück, John Couch Adams astronomer, and assistant director of the Cambridge Observatory ; D. L. Edwards, director of the Norman Lockyer Observatory, Sidmouth; Dr. M. A. Ellison; C. C. L. Gregory, director and Wilson observer, University of London Observatory ; F. Hoyle, lecturer in mathematics, University of Cambridge; Dr. A. Hunter, assistant, Royal Observatory, Greenwich ; Dr. E. H. Linfoot, lecturer in mathematics, University of Bristol ; P.J. Melotte, assistant, Royal Observatory, Greenwich; Prof. E. A. Milne, Rouse Ball professor of mathematics, University of Oxford; Dr. W. H. Steavenson, Gresham professor in astronomy.

\section{Institution of Electrical Engineers Scholarships}

THE Council of the Institution of Electrical Engineers is offering the following scholarships: Research Scholarships: Ferranti Scholarship (£250 a year for two years); Oliver Lodge Scholarship (£250 for one year); Swan Memorial Scholarship (£150 for one year); C. P. Sparks War Thanksgiving Fund (a grant not exceeding $£ 100$ for one year). Student Scholarships: Duddell Scholarship ( $£ 150$ a year for three years); Manville Scholarship (£150 a year for three years); Silvanus Thompson Scholarship ( $£ 100$ a year plus fees for two years); Salomons Scholarship ( $£ 100$ for one year); David Hughes Scholarship ( $£ 100$ for one year); Paul Scholarship (£50 a year for two years); Thorrowgood Scholarship (£25 a year for two years). Particulars and nomination forms, to be returned by April 15 (student scholarships) or June 1 (research scholarships), can be obtained from the Secretary, Institution of Electrical Engineers, Savoy Place, London, W.C.2.

\section{University of Leeds : Appointments}

ThE following appointments have been made in the University of Leeds : Dr. A. J. Brown, lately fellow of All Souls College, Oxford, to be professor of economics and head of the Department of Economics and Commerce; Dr. A. L. Roberts, senior lecturer in refractory materials, to be Livesey professor of coal, gas and fuel industries; Dr. G. S. Rushbrooke, Brotherton research lecturer in physical chemistry, to be lecturer in mathematical chemistry.

\section{The Night Sky in March}

FuLl moon occurs on March 7d. 03h. 15m. ס.T. and new moon on March 22d. 16h. 34m. The following conjunctions with the moon take place: March 4d. 02h., Saturn $4^{\circ}$ S.; March 12d. 15h., Jupiter $0.5^{\circ}$ N.; March 19d. 01h., Venus $5^{\circ}$ N.; March 20d. 20h., Mercury $7^{\circ}$ N.; March 21d. 04h., Mars $4^{\circ} \mathrm{N}$.; March 31d. 07h., Saturn $4^{\circ} \mathrm{S}$. In addition to these conjunctions with the moon, Mercury is in conjunction with Mars on March 16d. 17h., Mercury being $7^{\circ} \mathrm{N}$. Mercury, in inferior conjunction with the sun on March 8, is not favourably placed for observation in the early part of the month. On March 15 the planet rises at $5 \mathrm{~h} .42 \mathrm{~m}$, , and on March 31 at $5 \mathrm{~h} .06 \mathrm{~m}$., and can be seen in the eastern sky; but is a difficult object although its stellar magnitude is less than 1 at the end of March, because sunrise takes place only 35 minutes and 45 minutes later on the above dates. Venus is conspicuous as a morning star, rising at $5 \mathrm{~h} .02 \mathrm{~m} ., 4 \mathrm{~h} .57 \mathrm{~m}$. , and $4 \mathrm{~h} .40 \mathrm{~m}$., at the beginning, middle and end of the month, respectively. The surface of the illuminated disk varies from 0.643 to 0.736 and the stellar magnitude is about $-3 \cdot 6$ during the month. Mars is not well placed for observation. Jupiter can be seen close to $\beta$ Scorpii, rising at $0 \mathrm{~h} .48 \mathrm{~m} ., 23 \mathrm{~h} .54 \mathrm{~m}$. and $22 \mathrm{~h} .49 \mathrm{~m}$. at the beginning, middle and end of the month, respectively. The mean stellar magnitude of Jupiter is $-\mathbf{1 . 8}$ during March, and the planet is stationary on March 14. Saturn is visible up to the early morning hours, setting at $5 \mathrm{~h} .37 \mathrm{~m} ., 4 \mathrm{~h} .39 \mathrm{~m}$. and $3 \mathrm{~h} .35 \mathrm{~m}$. at the beginning, middle and end of the month respectively. The planet is easily recognized a little west of $\gamma$ and $\delta$ Cancris, its stellar magnitude being $\mathbf{0} \cdot \mathbf{2}$. Occultations of stars brighter than magnitude 6 are as follows: March 3d. 00h. $20 \cdot 3 \mathrm{~m} ., 52$ Gemi. $(D)$; March 29d. 22h. 46.8m., 37 Gemi. (D). The latitude of Greenwich is assumed and $D$ refers to disappearance. In addition to these occultations of stars, Uranus (mag. 6) is occulted on March 1d. 01h. $08 \cdot 1 \mathrm{~m}$. Spring equinox occurs on March 2ld. 11h.

\section{Announcements}

THE annual Mather Lecture of the Textile Institute will be delivered by Sir Walter Haworth, professor of chemistry in the University of Birmingham, on the occasion of the annual general meeting of the Institute on April 23; his subject will be "The Chemistry of the Polysaccharides".

Dr. F. W. HaYwood, who has been chief metallurgist of Wild-Barfield Electric Furnaces, Ltd., since 1938, has been appointed to the Board of the Company as technical director.

THE Challenger Society is prepared to consider applications for small grants in aid of research in marine biology or oceanography at a recognized laboratory during the year April 1947-April 1948. Applications, accompanied by details of the proposed research, should reach the honorary secretary, Mr. Dilwyn John, British Museum (Natural History), London, S.W.7, before April 19.

A Radrocommunication Convention, dealing particularly with war-time activities and their possible influence on peace-time development, has been arranged by the Institution of Electrical Engineers, and will be held at the Institution during March 25-28. Sessions will be devoted to such topics as longdistance point-to-point communication ; naval, military and aeronautical communication; pulse communication; short-distance communication ; direction finding; and war-time broadcasting. Sir Stanley Angwin will deliver an address on "Telecommunication in War".

Erratum.-In the letter by Dr. G. Whittingham on "The Luminous Decomposition of Nitrous Oxide", in Nature of February 15, p. 232: (a) 4 lines from foot of the first column, for "due to nitrous oxide" read "due to nitrogen peroxide"; (b) last sentence should read "Both these reactions require a high energy of activation ${ }^{10}$, and sufficient nitric oxide to give a visible glow with the atomic oxygen present is not produced until high temperatures are attained". 